AMERICAN INDIANS, AMERICAN JUSTICE 



\section{American Indians, American Justice}

Vine Deloria, Jr., and Clifford M. Lytle

$\checkmark \rightarrow$ University of Texas Press, Austin 
Copyright $(\mathcal{C} 1983$ by the University of Texas Press All rights reserved

Printed in the United States of America

Thirteenth paperback printing, 20Io

Requests for permission to reproduce material from this work should be sent to:

Permissions

University of Texas Press

P.O. Box 7819

Austin, TX 787 I3-7819

www.utexas.edu/utpress/about/bpermission.html

(0) The paper used in this book meets the minimum requirements of ANSI/NISO Z39.48-I992 (RI997) (Permanence of Paper).

LIBRARY OF CONGRESS CATALOGING-IN-PUBLICATION DATA

Deloria, Vine.

American Indians, American Justice.

Bibliography: $\mathrm{p}$.

Includes indexes.

I. Indians of North America-Courts. 2. Indians of North America-Legal status, laws, etc. 3. Courts-United States. I. Lytle, Clifford M. II. Title.

KF8224.C6D44 I983 347.73'I'08997 83-6975

ISBN 978-0-292-73834-8 (pbk.) 347.307108997 
TO ROBERT BLAKE,

who almost looked the part 
